\title{
Assessment of the contribution of the LOC387715 gene polymorphism in a family with exudative age-related macular degeneration and heterozygous CFH variant (Y402H)
}

\author{
Barkur S. Shastry
}

Received: 16 December 2006/ Accepted: 16 January 2007 / Published online: 7 February 2007

(C) The Japan Society of Human Genetics and Springer 2007

\begin{abstract}
Age-related macular degeneration (AMD) is a common cause of visual impairment in the elderly population in developed countries. The etiology of AMD is not completely understood but environmental and genetic factors have been implicated in the disease. Recently it has been documented that variations in the complement factor H (CFH) and LOC 387715 genes are the major risk factors that predispose individuals to dry and wet AMD. To investigate further the genetic contribution to AMD, we have analyzed the LOC 387715 gene in a non-smoking family with an exudative AMD and a heterozygous mutation $(\mathrm{Y} 402 \mathrm{H})$ in the $\mathrm{CFH}$ gene. Direct sequencing of the amplified product of exon 1 of the LOC 387715 gene identified a previously reported missense mutation (A69S) in this family. The affected individual is homozygous for the mutation and this sequence alteration was not identified in six age-matched controls. On the basis of this and other results it is tempting to speculate that the combined effect of variants in the CFH and LOC 387715 genes may contribute to the AMD phenotype in this family. Further studies on these and other susceptibility genes may provide clues on variable phenotypes, new preventive strategies and treatment options for AMD.
\end{abstract}

Keywords Polymorphism - Disease - Degeneration . Gene $\cdot$ Variant $\cdot$ Susceptibility

B. S. Shastry $(\bowtie)$

Department of Biological Sciences,

Oakland University, Rochester, MI, USA

e-mail: shastry@oakland.edu

\section{Introduction}

Age-related macular degeneration (AMD) is a complex and multifactorial eye disorder. It is the most common cause of blindness in the elderly population and affects approximately 50 million individuals worldwide (Klein et al. 2004; van Leeuwen et al. 2003). The condition causes loss of central vision affecting reading ability and driving. The disorder is divided into an exudative (or wet) and a non-exudative (dry) form. The dry form of the disorder is more common, accounting for about $90 \%$ of cases; the wet form of the condition is less common but is responsible for severe vision loss. While the dry form of the disorder is characterized by the presence of drusen and geographic atrophy, the wet form involves choroidal neovascularization and retinal pigment epithelial detachment. Ethnic and phenotypic variations in the disorder also exist and treatment options are limited for the majority of patients.

Several risk factors, such as smoking, diet, race and family history, have been consistently suggested as causative agents for AMD. Among these, genetic factors and smoking play a significant role in the pathogenesis of this disease (De Jong et al. 1997; Seddon et al. 1997; Klaver et al. 1998; Khan et al. 2006). Due to the late-onset nature of AMD, direct identification of heritable genes by genetic techniques is very difficult. However, several recent genome scan studies have identified susceptibility loci on 1q, 3p, 6q, 9q and 10q (Barral et al. 2006). Recently, several independent studies reported a strong association of the variant $\mathrm{Y} 402 \mathrm{H}$ in the complement factor $\mathrm{H}(\mathrm{CFH})$ gene on 1q32, and the A69S variant in the LOC 387715 gene (on 10q26) as major risk factors predisposing individuals to 
both forms of AMD (Haines et al. 2005; Klein et al. 2005; Edwards et al. 2005; Rivera et al. 2005; Sepp et al. 2006). In addition, a whole genome association study has identified a variant in the promoter region of the HTRA1 gene (on 10q26) that may also play a key role in AMD susceptibility (Dewan et al. 2006; Yang et al. 2006). Furthermore, ethnic variation in the frequency of the $\mathrm{Y} 402 \mathrm{H}$ variant (Grassi et al. 2006) and a strong association of the A69S variant with smoking (Schmidt et al. 2006) have been reported in some populations. In order to further our understanding of the genetic contribution to AMD, we have analyzed a familial case of AMD with a heterozygous $\mathrm{Y} 402 \mathrm{H}$ mutation and exudative macular degeneration.

\section{Materials and methods}

\section{Patients}

A family with three affected individuals related to the proband was identified; the clinical characteristics of this family have been described previously (Shastry and Trse 1999). Ocular examination of all patients by an experienced ophthalmologist revealed predominantly choroidal neovascularization and hemorrhage affecting both eyes. The symptoms began in the seventh decade of life (65-70 years). Detailed medical and family histories were obtained from patients and a pedigree was constructed (Fig. 1a). Information regarding a deceased individual was also obtained from patients. According to the international standardized AMD classification system, the family was diagnosed as having the exudative form of AMD (Fig. 1b). To the best of our knowledge this family did not have a history of smoking. This study was approved by the Institutional Review Board of Oakland University and all patients were informed of the purpose of the study.

Sample collection, PCR amplification and DNA sequencing

We collected venous blood from patients and unaffected family members and leukocyte DNA was extracted. Genomic DNA was amplified by the polymerase chain reaction (PCR) as described previously (Shastry 2006). Briefly, the PCR conditions were 30 cycles of $1.5 \mathrm{~min}$ at $94^{\circ} \mathrm{C}, 1 \mathrm{~min}$ at $60^{\circ} \mathrm{C}$ and $2 \mathrm{~min}$ at $72^{\circ} \mathrm{C}$ in a Fialsafe PCR buffer system supplied by Epicenter (Madison, WI). The amplified products were gel isolated, purified by phenol:chloroform extraction and ethanol precipitation. DNA sequencing was performed using the big dye terminator cycle sequencing method according to the procedure supplied by the manufacturer (Applied Biosystems, Foster city, CA) using the same forward and reverse primers used for amplification.
Fig. 1 a Pedigree of the agerelated macular degeneration (AMD) family studied in this report. The proband is denoted by an arrow. Filled symbols Affected individuals, open symbols unaffected individuals. b Fundus picture of the retina of an affected patient (II-2)

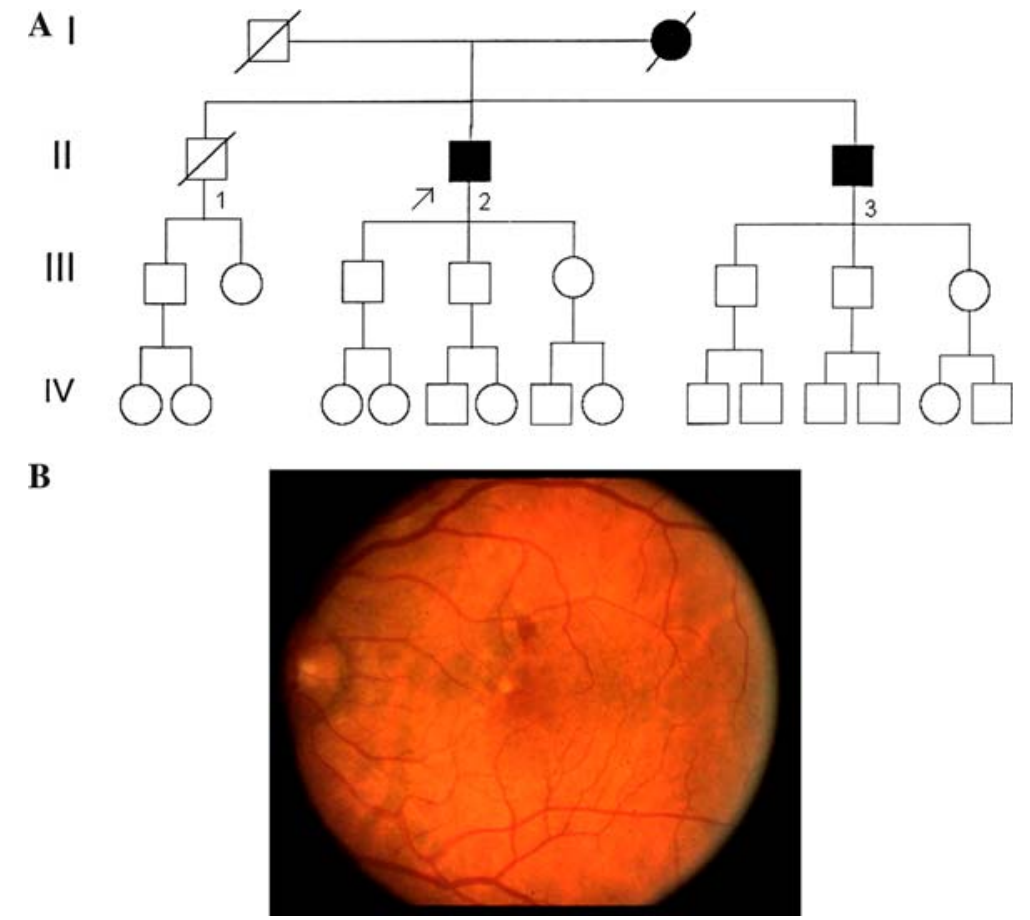




\section{Results}

We have previously reported (Shastry 2006) that the family shown in Fig. 1a contains a segregating variant $(\mathrm{Y} 402 \mathrm{H})$ in one of the alleles of the CFH gene. Since the affected individuals were non-smokers and have an exudative maculopathy, we were further prompted to analyze the second major gene (LOC 387715) for its contribution to the pathology of the disorder. When the amplified exon 1 of the LOC 387715 gene of an affected patient was sequenced, the same previously reported variant (A69S) was identified (Fig. 2). The patient is homozygous for this alteration and it was not found in six age-matched controls. When this family was previously analyzed for mutations in the RDS/ peripherin, bestrophin and glutathione peroxidase promoter region, no disease-causing polymorphism was detected. Therefore, it is very likely that these two genes are the candidate genes contributing either singly or in combination to the disorder.

\section{Discussion}

In developed countries, AMD is the leading cause of severe visual impairment in the elderly population. The etiology of AMD is complex and may involve genetic and environmental factors. Previous reports such as

\section{Unaffected}
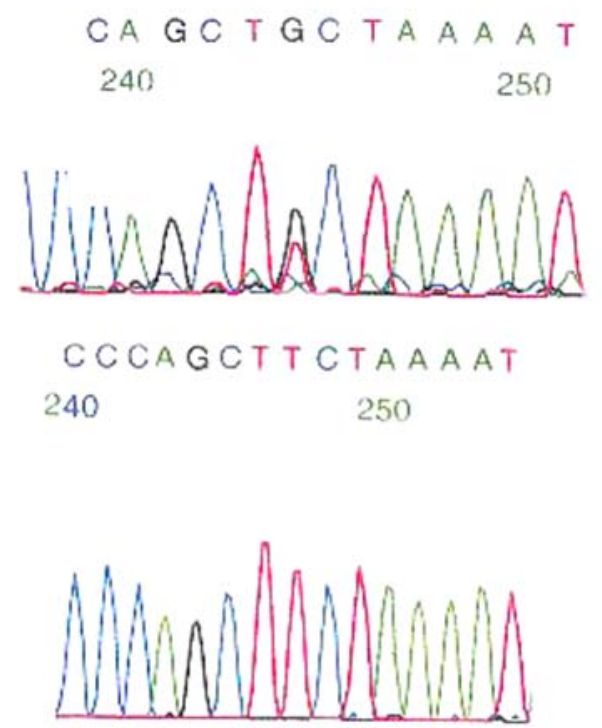

Affected

Fig. 2 Nucleotide sequence of the mutated part of exon 1 of the LOC 387715 gene. The homozygous nucleotide sequence change in the patient is $\mathrm{G} \rightarrow \mathrm{T}$, which results in the amino acid serine instead of the normal alanine population-based segregation analysis and twin studies support a role for genetic factors. Recently, it was found that variants in the CFH and LOC 387715 genes are the major genetic factors that predispose individuals to AMD. Although the allele frequency of $\mathrm{CFH}$ polymorphism varies among different populations (Grassi et al. 2006; Li et al. 2006; Conley et al. 2006), and is not associated with AMD in the Japanese population (Gotoh et al. 2006), many independent studies strongly suggest that it is an important etiological factor for both geographic atrophy and choroidal neovascularization (Sepp et al. 2006). Polymorphism in the second major gene LOC 387715 is strongly associated with smokers (Schmidt et al. 2006) although some studies did not find significant differences in risk allele frequency and smoking (Rivera et al. 2005; Conley et al. 2006). The contribution of this locus to AMD is also much weaker in the Russian population. Nevertheless, on the basis of several independent studies it has been consistently suggested that both genes independently contribute to disease risk and that they have multiplicative effects (Rivera et al. 2005; Schmidt et al. 2006).

In the present study, we have shown that the affected individuals in our family are homozygous for the risk allele (T/T) in the LOC 387715 gene. We have also previously reported that the same patients are heterozygous for the CFH variation (Shastry 2006). Although it is difficult to correlate genotype with phenotype, the present study may support the multiplicative model. Consistent with this idea, we have previously shown in a separate study (Shastry 2006) that when a single allele of the LOC 387715 gene alone is mutated (but with no mutation in the CFH gene) in a different family with a history of smoking, patients exhibited an extensive exudation and retinal detachment. This severe effect could be due to smoking since the single allele mutation in the LOC 387715 gene contributes only minimally to the disease risk (Schmidt et al. 2006) and smoking is known to modify the disease risk. The results of the present case suggest that homozygosity in the risk allele of the LOC 387715 gene reported to be associated with higher risk for the disease (Rivera et al. 2005; Schmidt et al. 2006), either alone or in combination with the heterozygous variant in the CFH gene, may contribute to the risk of AMD. Interestingly however, these digenic alterations do not seem to have any effect on the age of onset of the disorder in this family. Whatever the mechanism of disease pathogenesis, further studies on these susceptibility genes may provide information on variable phenotypes, new preventive strategies and treatment options for AMD. 
Acknowledgments I am thankful to Dr. Michael T. Trese of William Beaumont Hospital for providing the AMD family as well as fundus pictures of the affected individuals. This work was supported in part by the Oakland University Research Excellence Program in Biotechnology.

\section{References}

Barral S, Francis PJ, Schultz DW, Schain MB, Haynes C, Majewski J, Ott J, Acott T, Welber RG, Klein ML (2006) Expanded genome scan in extended families with agerelated macular degeneration. Invest Ophthalmol Vis Sci 47:5453-5459

Conley YP, Jakobsdottir J, Mah T, Weeks DE, Klein R, Kuller L, Ferrell RE, Gorin MB (2006) CFH, ELOVL 4, PLEKHA1 and LOC 387715 genes and susceptibility to age-related maculopathy: AREDS and CHS cohorts and meta-analyses. Hum Mol Genet 15:3206-3218

De Jong PT, Klaver CC, Wolfs RC, Assink JJ, Hofman A (1997) Familial aggregation of age-related maculopathy. Am J Ophthalmol 124:862-863

Dewan A, Liu MG, Hartman S, Zhang SSM, Liu DTL, Zhao C, Tam POS, Chan WM, Lam DSC, Snyder M, Barnstable C, Pang CP, Hoh J (2006) HTRA1 promoter polymorphism in wet age-related macular degeneration. Science 314: 989-992

Edwards AO, Ritter R III, Abel KJ, Manning A, Panhuysen C, Farrer LA (2005) Complement factor $\mathrm{H}$ polymorphism and age-related macular degeneration. Science 308:421-424

Gotoh N, Yamada R, Hiratani H, Renault V, Kuroiwa S, Monet N, Toyoda S, Chida S, Mandai M, Otani A, Yoshimura N, Matsuda F (2006) No association between complement factor $\mathrm{H}$ gene polymorphism and exudative age-related macular degeneration in Japanese. Hum Genet 120:139-143

Grassi MA, Fingert JH, Sheetz TE, Roos BR, Ritch R, West SK, Kawase K, Shire AM, Mullins RF, Stone EM (2006) Ethnic variation in $A M D$-associated complement factor $\mathrm{H}$ polymorphism p-Tyr 402 His. Hum Mutat 27:921-925

Haines JL, Hauser MA, Schmidt S, Scott WK, Olson LM, Gallins P, Spencer KL, Kwan SY, Noureddine M, Gilbert JR, Schnetz-Boutaud N, Agarwal A, Postel EA, PericakVance MA (2005) Complement factor $H$ variant increases the risk of age-related macular degeneration. Science 308:419-421

Khan JC, Thurlby DA, Shahid H, Clayton DG, Yates JR, Bradely M, Moore AT, Bird AC (2006) Smoking and agerelated macular degeneration: the number of pack years of cigarette smoking is a major determinant of risk for both geographic atrophy and choroidal neovascularization. Br J Ophthalmol 90:75-80
Klaver CC, Wolfs RC, Assink JJ, Van Duijn CM, Hofman A, de Jong PT (1998) Genetic risk of age-related maculopathy: population based familial aggregation study. Arch Ophthalmol 116:1646-1651

Klein R, Peto T, Bird A, Vannewkirk MR (2004) The epidemiology of age-related macular degeneration. Am J Ophthalmol 137:486-495

Klein RJ, Zeiss C, Chew EY, Tsai JY, Sackler RS, Haynes C, Henning AK, Sangiovanni JP, Mane SM, Mayne ST, Bracken MB, Ferris FL, Ott J, Barnstable C, Hoh J (2005) Complement factor $\mathrm{H}$ polymorphism in age-related macular degeneration. Science 308:385-389

Li L, Chen SJ, Cheng CY, Yen MY, Lee FL, Lin MW, Hsu WM, Wei YH (2006) Association of the Y402H polymorphism in complement factor $\mathrm{H}$ gene and neovascular age-related macular degeneration in Chinese population. Invest Ophthalmol Vis Sci 47:3242-3246

Rivera A, Fisher SA, Fritsche LG, Keilhauer CN, Lichtner P, Meitinger T, Weber BHF (2005) Hypothetical LOC 387715 is a second major susceptibility gene for age-related macular degeneration, contributing independently of complement factor $\mathrm{H}$ to disease risk. Hum Mol Genet 14:3227-3236

Schmidt S, Hauser MA, Scott WK, Postel EA, Agarwal A, Gallins P, Wong F, Chen YS, Spencer K, Schnetz-Boutaud N, Haines JL, Pericak-Vance MA (2006) Cigarette smoking strongly modifies the association of LOC 387715 and agerelated macular degeneration. Am J Hum Genet 78:852-863

Seddon JM, Ajani UA, Mitchell BD (1997) Familial aggregation of age-related maculopathy. Am J Ophthalmol 123:199-206

Sepp T, Khan JC, Thurlby DA, Shahid H, Clayton DG, Moore AT, Bird AC, Yates JR (2006) Complement factor $\mathrm{H}$ variant $\mathrm{Y} 402 \mathrm{H}$ is a major risk determinant for geographic atrophy and choroidal neovascularization in smokers and non-smokers. Invest Ophthalmol Vis Sci 47:536-540

Shastry BS (2006) Further support for the common variants in complement factor $\mathrm{H}(\mathrm{Y} 402 \mathrm{H})$ and LOC 387715 (A69S) as major risk factors for age-related macular degeneration. Ophthalmologica 220:291-295

Shastry BS, Trse MT (1999) Evaluation of the peripherin/RDS gene as a candidate gene in families with age-related macular degeneration. Ophthalmologica 213:165-170

Van Leeuwen R, Klaver CC, Vingerling JR, Hofman A, de Jong PT (2003) The risk and natural course of age-related maculopathy: follow-up at $61 / 2$ years in the Rotterdam study. Arch Ophthalmol 121:519-526

Yang ZL, Camp NJ, Sun H, Tong ZZ, Gibbs D, Cameron DJ, Chen HY, Zhao Y, Pearson E, Li X, Chien J, DeWan A, Harmon J, Bernstein PS, Shridhar V, Zabriskie NA, Hoh J, Howes K, Zhang K (2006) A variant of the HTRA1 gene increases susceptibility to age-related macular degeneration. Science 314:992-993 